ISSN 2620-6760, Vol.3, No. 2, Oktober 2020

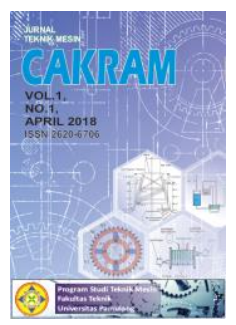

\title{
ANALISIS PERBEDAAN USIA PAKAI MOLDING BERBAHAN BAJA PERKAKAS SKS 12, SLEIPNER A88, DAN SKH 55 UNTUK PRODUK MUR (NUT) BAJA S50C
}

\author{
Tatang Suryana \\ Program Studi Teknik Mesin, Universitas Pamulang, Jl. Surya Kencana No.1, Tangerang Selatan, Indonesia. \\ E-mail : mesin@gmail.com \\ Masuk : 3 September 2020 \\ Direvisi : 21 September 2020 \\ Disetujui : 8 Oktober 2020
}

\begin{abstract}
Abstrak:Penelitian ini mempelajari usia pakai molding untuk produk mur. Bahan molding yang digunakan baja perkakas SKS 12, SLEIPNER A88 dan SKH 55, sedangkan bahan produk mur yang akan dihasilkan adalah baja karbon seri S50C. Ketiga bahan molding ini diujikan di industri. Pembuatan mur meliputi uji dimensi dengan mengukur toleransi dimensi mur dan uji usia pakai dengan melihat jumlah produk yang dihasilkan. Pengujian ini dilanjutkan dengan uji kekerasan mikro pada bagian sisi dalam dari molding. Usia pakai baja perkakas SKS 12 sebanyak 40.105 produk dengan toleransi dimensi berubah menjadi $0.055 \mathrm{~mm}$, baja perkakas SLEIPNER A88 sebanyak 110.703 produk dengan toleransi dimensi berubah menjadi $0.053 \mathrm{~mm}$, baja perkakas SKH 55 sebanyak100.404 produk dengan toleransi dimensi berubah menjadi $0.054 \mathrm{~mm}$, uji kekerasan mikro baja perkakas menunjukkan bagian terdalam sisi molding rata-rata lebih rendah dibandingkan dengan bagian tengah. Molding berbahan SKS 12 memiliki usia paling pendek, Molding berbahan SKH 55 memiliki usia panjang, dan Molding berbahan SLEIPNER A88 memiliki usia paling tinggi dan sedikit lebih tinggi dari SKH 55. Usia pakai SKS 12 dua sampai tiga kali pakai, sedangkan usia pakai SKH 55danSLEIPNER A88 diperkirakan lebih dari tiga kali pakai. Kata kunci: baja perkakas, sks 12, skh 55, sleipner a88, mur s50c,molding, uji kekerasan.
\end{abstract}

Abstract:This research studies the age of molding for nut products. Molding materials used are tool steel SKS 12, SLEIPNER A88 and SKH 55, while nut products to be produced is a series S50C carbon steel. All molding materials were tested in the industry. These included test to measure the dimensions of the nut and the dimensional tolerance test for some products. This test is followed by a micro hardness test on the inner side of the molding. The tool steel SKS 12 can be performed for 40.105 pieces of product with a dimensional tolerance into $0.055 \mathrm{~mm}$, tool steel SLEIPNER A88 is used to produce 110.703 pieces of product with a dimensional tolerance into $0.053 \mathrm{~mm}$, tool steel SKH 55 is used for 100.404 pieces of product with tolerance dimensionsinto0.054 mm standard tolerance. Micro hardness test for showed tool steel that the deepest part of the molding on average lower than in the central part of the molding. molding made of SKS 12 has the shortest life, molding made of SKH 55 has a long life, and molding made from SLEIPNER A88 to have the highest age and slightly higher than SKH 55. The lifetime SKS 12 is usually two to three times the wear, whereas the time lifetime SKH 55 and SLEIPNER A88 estimated at more than three times thewear.

Keywords: Tool steel, sks 12, skh 55, sleipner a88, nuts50c molding, hardness test. 


\section{PENDAHULUAN}

Pada saat ini dunia industri otomotif di Indonesia berkembang dengan pesatnya, dan ikut serta dalam menunjang pembangunan yang sedang giat dilaksanakan. Di sektor industri yang mengolah logam, baja perkakas semakin banyak dibutuhkan baik dalam kehidupan sehari-hari ataupun untuk menunjang salah satu kebutuhan dalam industri. Industri otomotif Indonesia saat ini masih kalah dengan Thailand. Salah satu kendalanya adalah kurangnya industri komponen dalam negeri. Industri komponen otomotif di Thailand sudah mencapai 2.000-an. Sedangkan di Indonesia baru sekitar 800 industri komponen. Karena itulah industri komponen dalam negeri adalah salah satu hal yang harus dikembangkan. Pengembangan industri komponen dalam negeri dapat membantu Indonesia menjadi negara industri otomotif untuk mengalahkan negeri gajah putihitu. Indonesia bertekad untuk bersaing dengan Thailand sebagai negara industri otomotif. Ada beberapa faktor yang harus berjalan dengan baik sehingga Indonesia bisa menjadi negara industri otomotif. Adapun peran pemerintah yang bisa membuat industri otomotif Indonesia bangkit salah satunya adalah infrastruktur. Dukungan pemerintah terhadap usaha kecil dan menengah (UKM) diIndonesia pun berpengaruh. Indonesia perlahan akan mampu menggantikan Thailand sebagai pusat produksi otomotif utama di ASEAN. Hal ini memiliki implikasi besar bagi produsen dan penyuplai suku cadang otomotif serta pemangku kebijakan di kedua negara. Buktinya jelas bahwa dalam hal tren output produksi kendaraan, perkembangan kebijakan dan perbaikan infrastruktur, Indonesia akan terus meningkatkan kapasitas produksi, konsumsi domestik dan volume ekspor sekaligus. Produsen otomotif dan pemangku kebijakan Indonesia, Thailand dan negara- negara lainnyapun tentu akan mempertimbangkan implikasiini. Pada industri-industri yang bergerak di bidang logam, baja perkakas adalah baja yang banyak digunakan untuk komponen alat-alat produksi yaitu pada mesin potong, mesin bubut dan lain-lain. Dalam aplikasinya baja perkakas digunakan untuk forging dies, dies casting, punch danmolding.[1] Material molding SKS 12 hanya mampu mencapai 40.000 produk. Rata-rata produk Mur yang dihasilkan melalui proses blanking perhari sebanyak 21.000 produk, maka perlu adanya penelitian lanjut tentang material molding yang cocok untuk proses blanking terhadap material S50C dan mampu mencapai 100.000 kali blanking, dikarenakan order produk Mur rata-rataperbulan mencapai 25.000 produk. Maka variasi penelitian tentang material molding yang baik sangat diperlukan guna menunjang proses produksi mur.[2]

Proses pembentukan logam dengan mempergunakan gaya tekan untuk mengubah bentuk atau ukuran dari logam yang dikerjakan. Secara umum dapat dibagi menjadi 4 kelompok besar yaitu : Pressing, Drawing, Bending, Shearing.[3] Kecepatan proses pembentukan merupakan aspek penting yang dapat mempengaruhi materi dan menghasilkan variasi dalam hasil akhir.[4] Deformasi lambat selama proses pembentukan dingin akan memiliki pengaruh yang nyata pada ketahanan bahan untuk membentuk, dengan peningkatan suhu dan dengan peningkatan kecepatan membentuk, resistensi terhadap pembentukan sering diturunkan.[5] Namun, peningkatan mendadak dalam kecepatan terbentuk selama dingin dapat meningkatkanketahanan material.[6] Berdasarkan proses pengerjaannya dapat dibagi menjadi 2 bagian yaitu : Proses Pengerjaan Panas (Hot Working Process), Proses Pengerjaan dingin (Cold Working Process).[7] Perlakuan panas merupakan suatu proses pemanasan pada baja dalam keadaan padat untuk mengubah struktur mikro dan sifat- sifat fisik baja seperti Quenching, Anneling,Normalizing, Tempering.[8]

\section{METODOLOGI}

Penelitian ini menggunakan metode eksperimen, ekperimen ini dilakukan secara terus-menerus. Dimana keausan molding akan mempengaruhi kualitas dimensi produk sehingga produk tersebut menjadi cacat dimensi. Pengambilan data diperoleh dengan simulasi di lapangan,dimana pada inspeksi awal diambil contoh produk sebanyak 30 produk untuk mengetahui kestabilan proses pada saat awal proses Setelah proses produksi berjalan normal akan dilakukan pengambilan contoh produk setiap 3 jam sekali atau seharidilakukan selama 6 kali. Hingga terjadi keausan pada molding. 


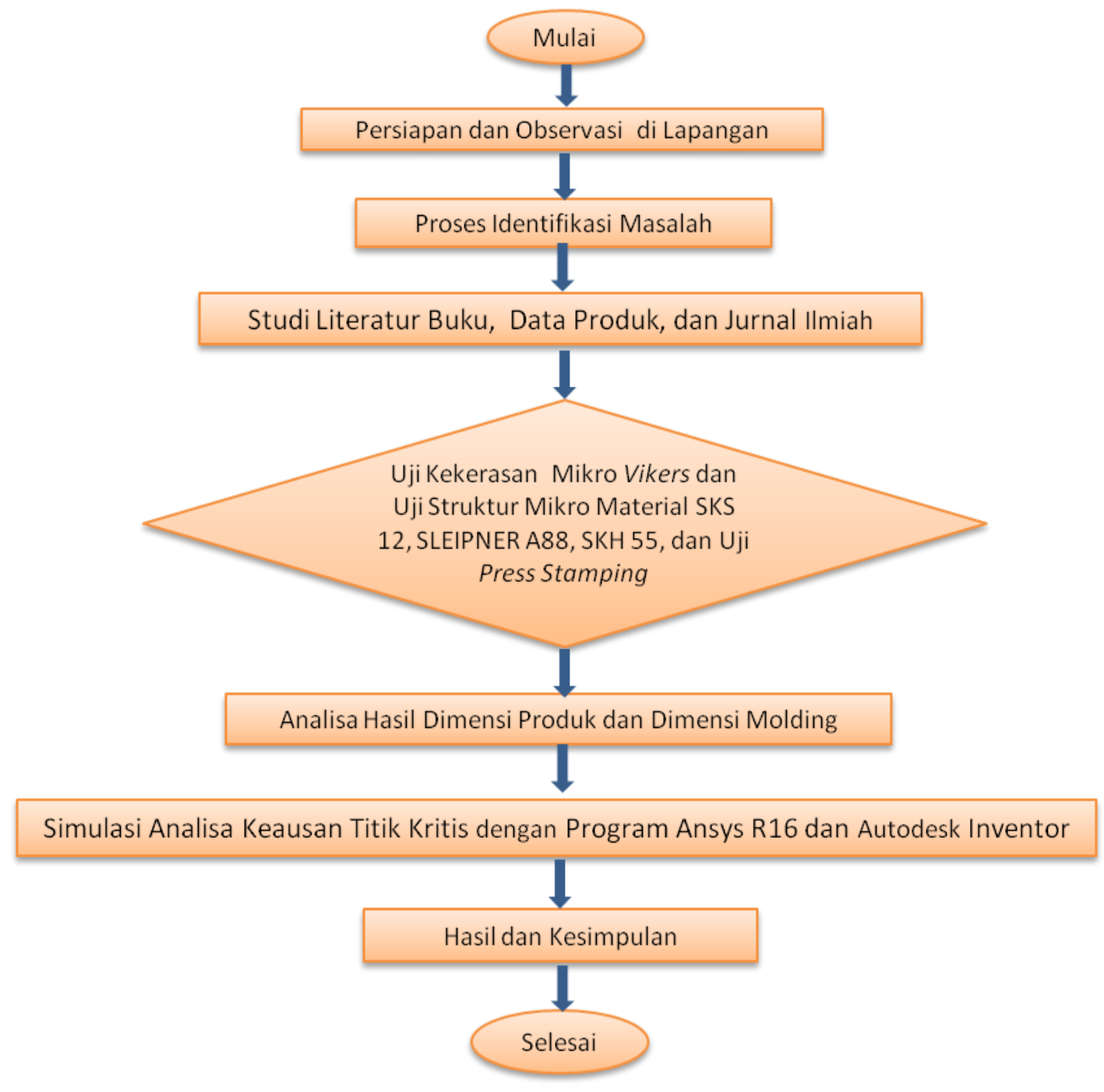

Gambar 1. Diagram Alir Penelitian

Diagram alir penelitian ini dimulai dengan tahap persiapan serta observasi lapangan, dilanjutkan dengan proses identifikasi permasalahan dilapangan. Setelah itu dilanjutkan dengan mencari data-data studi literatur, setelah semua data studi literatur didapatkan dilanjutkan dengan persiapan bahan material uji, material uji memilikibeberapa macam tingkatan kekerasan material dan kandungan material, tingkatan kekerasan dapat dilihat dengan melakukan uji kekerasan. Setelah itu dianalisa hasil kekerasannya, kemudian dilanjutkan pengujian material molding dilapangan, dan dilanjutkan dengan menganalisa hasil pengujian,berupa secara visual dan dimensi maupun uji kekerasan setelah proses press stamping, setelah menganalisa data- data diperoleh hasil yang beragam. Maka dari hasil analisa data-data tersebut dapat diambil kesimpulan dari keseluruhan dan prosesdinyatakan selesai. 


\section{HASIL DAN PEMBAHASAN}

\section{Waktu pakai molding}

Proses pengujian yang pertama (pada gambar 2 grafik dibawah ini) menggunakan material SKS 12 padamesin press stamping AIDA 110 ton, dengan kecepatan 25 SPM ( stroke per menit) menghasilkan jumlah produk sebanyak 40.105 produk. Proses pengujian yang kedua menggunakan material SLEIPNER A88 pada mesin press stamping AIDA 110 ton, dengan kecepatan 25 SPM ( stroke per menit) menghasilkan jumlah produk sebanyak 110.703 produk. Proses pengujian yang ketiga menggunakan material SKH 55 pada mesin press stamping AIDA 110 ton, dengan kecepatan 25 SPM ( stroke per menit) menghasilkan jumlah produk sebanyak 100.404 produk.

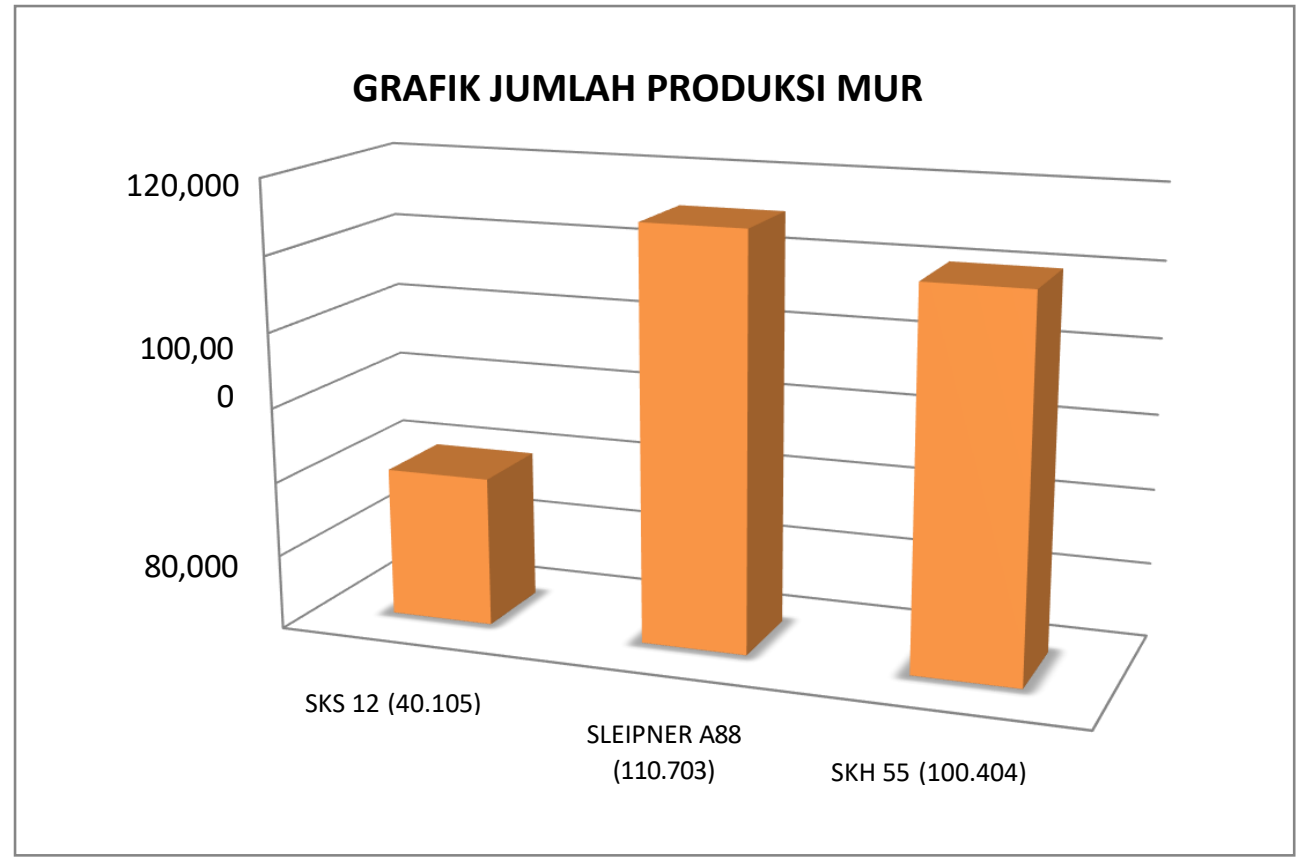

Gambar 2. Grafik Produksi Mur.

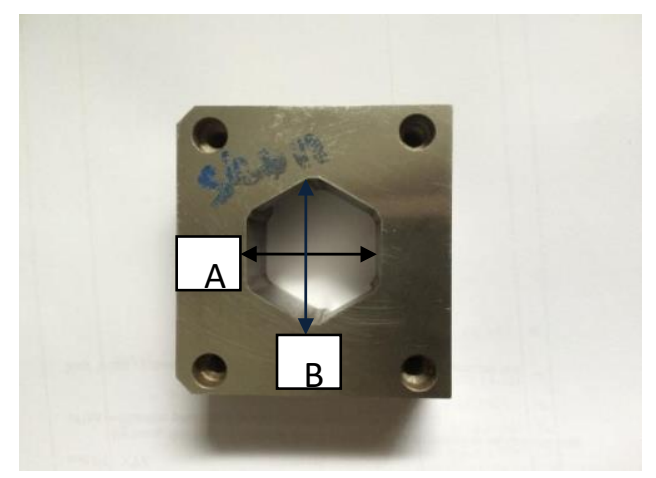

Gambar 3. molding sebelum pengujian.

Pada (gambar 3) merupakan bentuk molding sebelum dilakukan pengujian, dimensi $\mathrm{A}=35.00-35.05 \mathrm{~mm}$, dan dimensi $\mathrm{B}=31.60-31.65 \mathrm{~mm}$ (pada material SKS 12) ditunjukan pada tabel 1. standart spesifikasi. 
Tatang Suryana, Analisis Perbedaan Usia Pakai Molding Berbahan Baja Perkakas SKS 12, Sleipner A88, dan SKH 55 Untuk Produk Mur (NUT) Baja S50C

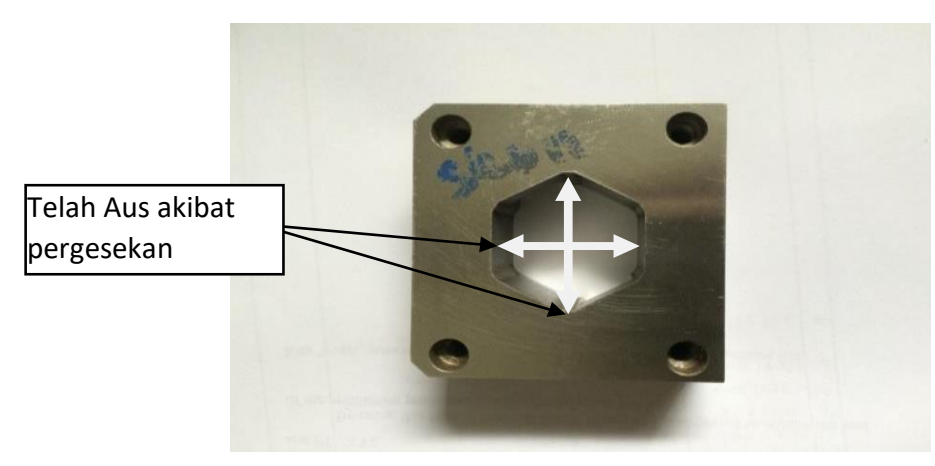

Gambar 4. Molding setelah dilakukan Pengujian.

Pada gambar 4 merupakan bentuk molding setelah dilakukan pengujian, dimensi A menjadi $35.06 \mathrm{~mm}$, dan dimensi B menjadi $31.70 \mathrm{~mm}$ (pada material SKS 12) ditunjukan pada tabel 1.

Tabel 1. Spesifikasi diameter Molding yang telah digunakan.

\begin{tabular}{|c|l|c|l|l|}
\hline \multirow{2}{*}{ No. } & \multicolumn{4}{|c|}{ Diamater Molding } \\
\cline { 2 - 5 } & Standar Spesifikasi & SKS 12 & SLEIPNER A88 & SKH 55 \\
\hline A & $35.00-35.05 \mathrm{~mm}$ & $35.06 \mathrm{~mm}$ & $35.053 \mathrm{~mm}$ & $35.054 \mathrm{~mm}$ \\
\hline B & $31.60-31.65 \mathrm{~mm}$ & $31.70 \mathrm{~mm}$ & $31.68 \mathrm{~mm}$ & $31.69 \mathrm{~mm}$ \\
\hline
\end{tabular}

Pada tabel diatas terlihat ukuran spesifikasi keausan tiap-tiap material molding, dimana pada diameter molding mengalami cacatdimensiproduk diatas spesifikasi standar yang sudah ditetapkan.

4.1 Kekerasan molding baja perkakas SKS 12, SLEIPNER A88 dan SKH 55

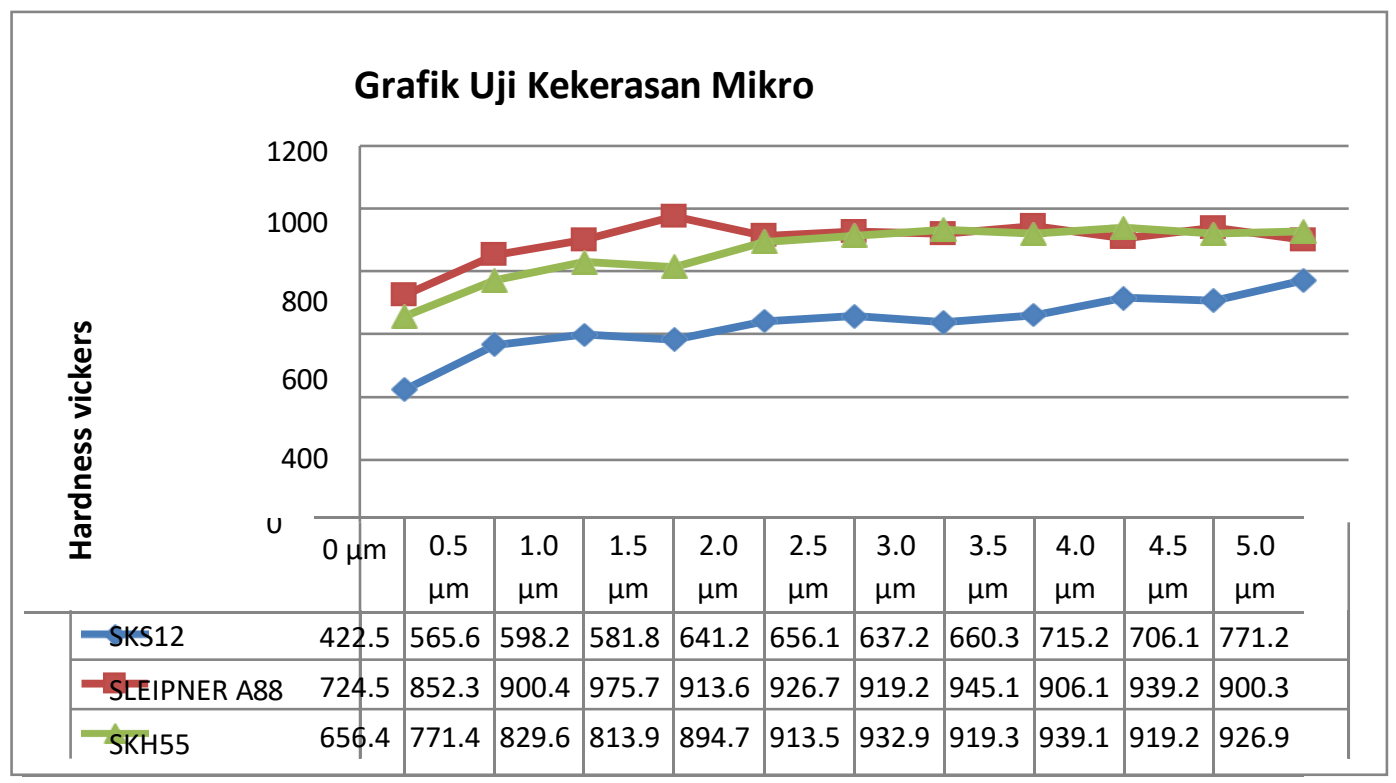

Gambar 5. Grafik uji kekerasan mikro vickers baja perkakas SKS 12, SLEIPNER A88, SKH 55. 
Pada Gambar 5 grafik diatas menunjukkan bahwa bagian terdalam dari 0,0 - 5,0 Mikro meter setiap material mempunyai nilai uji kekerasan yang paling rendah, karena adanya pergesekan antara molding dengan punch, dimana akan menimbulkan panas dan menyebabkan dimensi cepat aus. Material SKS 12 menunjukkan kecepatan aus yang lebih cepat dibandingkan material yang lain, dan material SLEIPNER A88 mempunyai rata-rata nilai grafik yang paling tinggi dan sedikit lebih tinggi dari material SKH 55, hal ini menunjukkan umur material SLEIPNER A88 dan SKH 55 lebih panjang daripada material SKS 12. Proses pengujian kekerasan ini menggunakan alat mikro vickers clark intrument dengan load $100 \mathrm{gf}$ selama 10 detik pada setiap material.

\section{Simulasi Proses Press Stamping}

Penelitian ini menggunakan program autodesk inventor dan ansys R16 dilakukan melalui tiga tahapan yaitu pertama menggunakan material Molding berbahan dasar SKS12, kemudian dilanjutkan pada SLEIPNER A88 dan terakhir menggunakan material SKH 55. Pada setiap pengujian dilakukan pada mesin yang sama yaitu mesin press stamping AIDA berkapasitas 110 Ton, dimana pengujian ini dilakukan secara terus- menerus hingga molding mengalami proses keausan dimensi. Dengan ditandai pada kecacatan produk berupa cacat dimensi (outside) diameter luar produk.

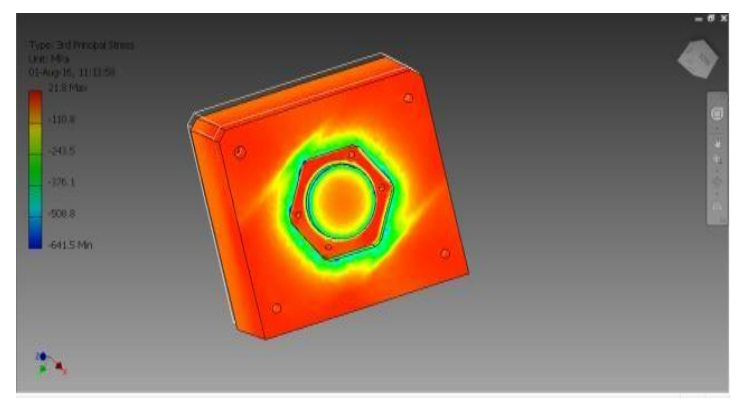

Gambar 6. Autodesk Inventor Stress Analysis molding SKS 12

Pada (gambar 6) terlihat aliran titik kritis pada molding dimana bagian yang berwana merah dan kuning merupakan titik kritis yang paling tinggi pada posisi di pinggir.

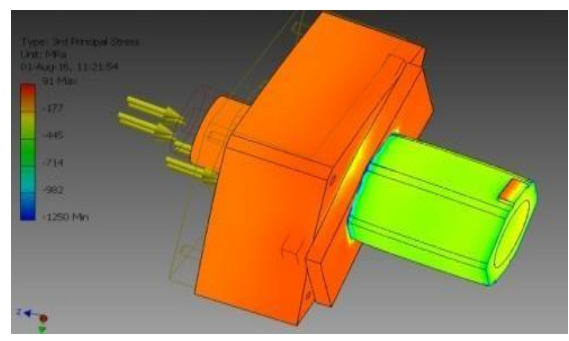

Gambar 7. Autodesk Inventor Stress Analysis Assy Die. 
Pada Gambar 7 diatas menunjukkan distribusi tegangan (stress) analisis berlangsung pada pinggir molding yang kemudian diteruskan ke bahan produk, yang selanjutnyabergesekan dengan punch, dimana punch akan mengalami distribusi tegangan (stress) analisis yang mengakibatkan bahan produk terpotong. Sehingga produk nut (mur) dapat terbentuk akibat gesekan antara molding dengan punch, yang terjadi berulang - ulang selama proses pembuatan produk mur berlangsung.

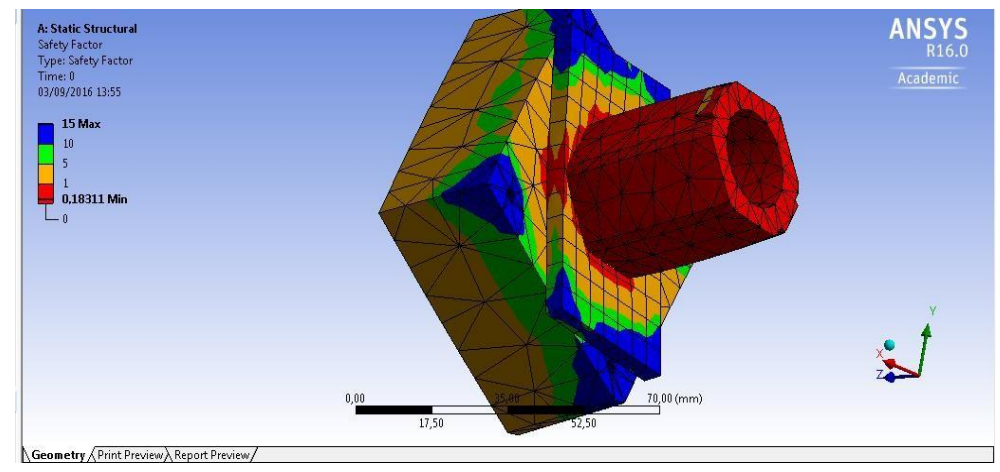

Gambar 8. Ansys R16 Safety factor analysis assy die.

Pada program ansys R16 (gambar 8) diperlihatkan pada masing-masing material SKS 12, SLEIPNER A88 dan SKH 55 gambar equivalen elastic strain analysis, stress analysis, life clycle analysis, safety factor analysis. Dimana pada setiap gambar program analisa menunjukkan distribusi tegangan dengan simbol warnawarni yang menunjukkan titik-titik kritis dari setiap material molding.

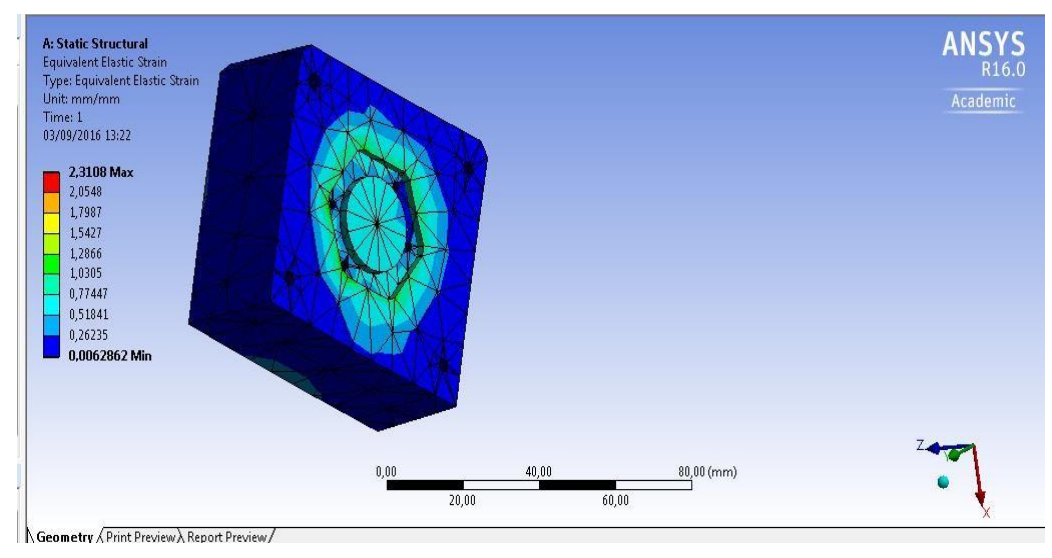

Gambar 9. Ansys R16 Equivalen elastic strain analysis material SKS 12. 


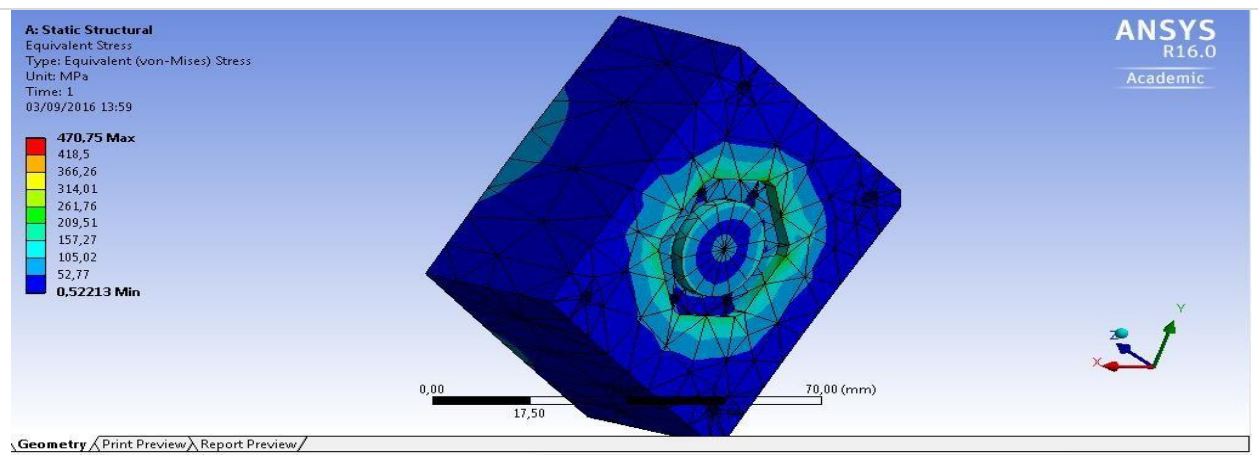

Gambar 10. Ansys R16 Stress analysis material SLEIPNER A88.

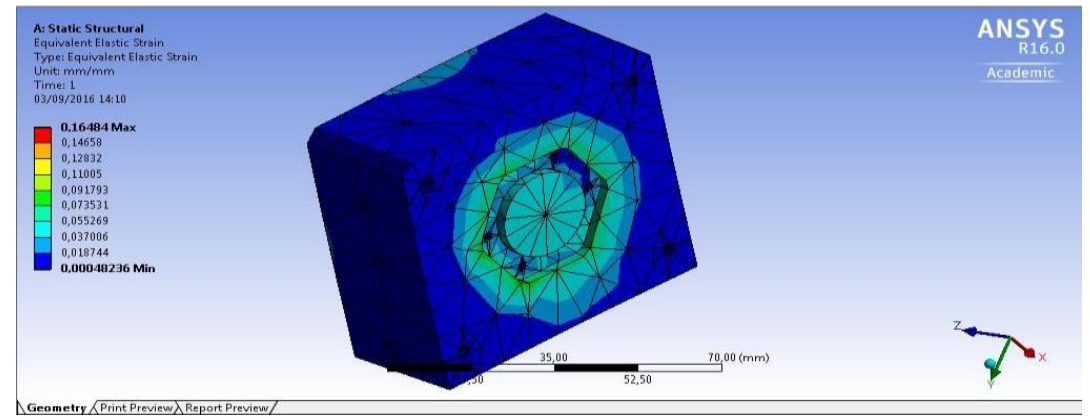

Gambar 11. Ansys R16 Safety factor analysis material SKH55.

Pada gambar diatas (gambar 9,10,11) menunjukan bagian kritis digambarkan pada bagian pinggir material yang berwarna hijau kekuning-kuningan, dimana warna tersebut merupakan bagian yang mengalami tegangan statis yang besar dibandingan dengan bagian tengah atau pinggir bagian luar dari material.

\section{KESIMPULAN}

1. Pada saat proses pengujian dilapangan pada material SKS12 menghasilkan 40.105 produk, material SLEIPNER A88 menghasilkan 110.703 produk, dan SKH 55 menghasilkan 100.404 produk.

2. Pada gambar grafik uji kekerasan struktur mikro vickers menunjukkan bahwa bagian pinggir pada molding memiliki nilai kekerasan yang lebih rendah dibandingkan dari bagian tengah molding yang disebabkan oleh gesekan berulang-ulang antaramoldingdengan punch sehingga mengalami deformasi material.

3. Pada gambar simulasi stress analysis pada program autodesk inventor maupun ansys R16 menunjukkan bahwa distribusi tegangan dan titik kristis yang berwarna kemerahan pada material SKS 12 lebih besar dan banyak bila dibandingkan pada material SLEIPNER A88 dan SKH 55, ini menunjukkan bahwa material SKS 12 lebih tinggi distribusi tegangannya jika dibandingkan dengan material SLEIPNER A88 dan SKH55. 


\section{DAFTAR PUSTAKA}

[1] Annudep,S.I. Ramesha. N.I : Desaign And Analysis Of Blangking And Bending Press Tool To Produce Anchor Bracket Component. International Journal of Research Engineering and Technology:IJRET International. Vol 04.04.2015. page1035-1039.

[2] ASM Handbook. Vol. 1; properties and selectionsirons. stells. and high performance alloys. ASM international;1993.

[3] Djaprie, Sriati ;Teknologi Mekanik, Jakarta : Erlangga.1997 ;135-136

[4] Ivana Suchy ;Hand Book of Die Desain Second Edition. USA: Mc Graw Hill;2006.

[5] Kim.S.H.I Choi.K.K.I : Research On Improvment Of Blank Precision And Life Span Extension OfNail Clipper Die With Uneve Shear Area. International Journal of Advanced Science andThecnology:IJAST International.Vol 54. 05.2013. page 89-95.

[6] Momami.E.A.I Rawadeh.I.I : An Application Of Finite Element Methode And Design Of Experiment In The Optimazion Of SheetMetalBlanking Process. Jordan Journal of Machine and Industrial Engineering :JJMIE.Vol 2.03.2008. page 53-63.

[7] Subramayam.P.I. Rajashekar.B.I, Damodhar.B.: Process Of Press Tool Desaign And Its Manufacturing For Blanking Operation. International Journal of innovative research in science Engineering and Technology: IJIRSET International.Vol 05. 05. 2016. page8602-8609.

[8] Shaikh.R.S.I Gaonkar.R.R.Ishaikh.I. Shaikh. M.I Shaikh. S.I : A Review On Factors Affecting The Sheet Metal Blanking Process. International Journal of Modern Engineering Research :IJMER International.Vol 05.03.2015. page 71-76. 